\section{Impact of Different Cover Crops and Types of Transplanter Mounted Subsoiler Shanks on Tomato Yield}

\author{
Ted S. Kornecki ${ }^{1}$ and Francisco J. Arriaga \\ USDA-ARS, National Soil Dynamics Laboratory, Conservation Systems \\ Research, 411 South Donahue Drive, Auburn, AL 36832
}

Additional index words. no-till tomato, cover crops, roller/crimper, vegetable transplanter, subsoiler shank

\begin{abstract}
A 4-year experiment with different tillage practices for tomatoes was conducted in Cullman, AL, to determine the impact of plastic mulch (control), rye and crimson clover cover crops, and different subsoiler shanks (no shank, slim $13 \mathrm{~mm}$ thick and wide $20 \mathrm{~mm}$ thick) on tomato yield. Overall, during 2007 and 2008 growing seasons, total tomato yields (between 58,905 and $60,115 \mathrm{~kg} \cdot \mathrm{ha}^{-1}$ ) and marketable tomato yields (between 48,331 and $49,873 \mathrm{~kg} \cdot \mathrm{ha}^{-1}$ ) were significantly higher than in 2005 and 2006 (between 49,656 and 50,151 kg.ha' and from 40,581 to $41,194 \mathrm{~kg} \cdot \mathrm{ha}^{-1}$ ) for total and marketable tomato yields, respectively. During the 2006 and 2008 growing seasons, plastic cover provided higher yield $\left(60,921\right.$ and $\left.73,718 \mathrm{~kg} \cdot \mathrm{ha}^{-1}\right)$ compared with rye and crimson clover overall shank treatments. In 2007, higher yield was produced following rye without shank $\left(70,577 \mathrm{~kg} \cdot \mathrm{ha}^{-1}\right)$ compared with plastic mulch and crimson clover treatments. Across years, tomato yield after crimson clover was lower compared with rye and plastic. Percent of marketable fruit yield to total yield exceeded $80 \%$ in all treatments, including the plastic control. Cover crops and shank treatments did not affect percentage of marketable tomato yield compared with total tomato yield. Cover crops, especially rye, can provide an alternative in tomato production for those producers not wanting to use plastic mulches.
\end{abstract}

Cover crops have become a vital part of no-till systems for row crops in the southern United States; however, no-till systems using cover crops for vegetable production have not been widely adopted. Only $12 \%$ of the Alabama vegetable production area is under notill production (CTIC, 2004). A limiting factor is the lack of equipment (rollers/crimpers) needed to manage tall cover crops such as cereal winter rye (Secale cereale L.) and winter crimson clover (Trifolium incarnatum L.) in flat or ridge vegetable production systems. In addition, the tradition of plowing/ disking soil in vegetable production is strong in this region. However, there is interest in the area to use cover crops in no-till vegetable systems to reduce cost and protect soil resources while increasing or maintaining yields. Cover crop use can improve soil physical properties, increase soil organic carbon, conserve soil water, reduce surface runoff, and recycle nutrients (Hubbell and Sartain, 1980; Mansoer et al., 1997; Reeves, 1994).

Cereal rye is widely used in Alabama and can produce between 3 and 11 tons/ha of

Received for publication 22 Oct. 2010. Accepted for publication 19 Feb. 2011.

We acknowledge Mr. Arnold Caylor, superintendent at the Horticultural Research Station, Cullman, $\mathrm{AL}$, for his technical assistance.

The use of trade names or company names does not imply endorsement by the USDA-Agricultural Research Service.

${ }^{1}$ To whom reprint requests should be addressed; e-mail ted.kornecki@ars.usda.gov. biomass providing benefits such as alleopathic weed suppression and a mulch effect resulting from enhanced residue cover (Barnes and Putnam, 1983). Another widely used cover crop is the legume crimson clover, which can be used in a mixture or alone to fix atmospheric nitrogen.

To realize benefits of cover crops, the cover crops must be managed appropriately to avoid cash crop planting problems. These covers must be ended at the appropriate growth stage to generate maximum biomass. A common method to end cover crops is the use of herbicides because spraying is relatively fast and effective. However, because rye is very tall and lodges in multiple directions, planting efficiency of a cash crop can be reduced as a result of frequent delays required to clean accumulated cover residues from planting units (Kornecki et al., 2009).

Flattening and crimping cover crops by to planting of a cash crop is widely used in South America (especially in Brazil) to successfully end cover crops without herbicides (Derpsch et al., 1991). Because of potential environmental and monetary benefits (no use of herbicides), this technology is now receiving increased interest in North America. Ashford and Reeves (2003) indicated that when rolling was conducted at the appropriate plant growth stage (i.e., soft dough), the roller was equally effective (as chemical herbicides) at ending cover crops (94\%). They concluded that rye mortality above $90 \%$ was sufficient to begin cash crop mechanical rollers in the direction parallel planting as a result of accelerated cover crop senescence.

Conventional tomato production typically includes deep tillage and bedded plastic mulch to minimize weed populations. Conventional tillage increases soil erosion and nutrient loss, reduces organic carbon, and increases soil strength (Blough et al., 1990; Mahboubi et al., 1993). Plastic mulch is expensive and could cause environmental problems if not removed from the field after harvest. According to Teasdale and Abdul-Baki (1995), plastic mulch increased soil temperature, which caused tomatoes grown under the plastic to produce fruit early in the season. In contrast, tomatoes grown under hairy vetch mulch systems produced fruit that was more uniform throughout the season (Abdul-Baki et al., 1996). Therefore, no-till tomato production with cover crops might be a good alternative to protect the soil and the environment while decreasing tomato production costs.

The objective of this study was to evaluate the effects of two different cover crops (rye and crimson clover) on tomato (Lycopersicon esculentum L.) yield and quality compared with plastic cover and shanks attached to a transplanter.

\section{Materials and Methods}

The study was conducted during the 20052008 growing seasons at the Northern Alabama Horticultural Research Station in Cullman, AL. The study was initiated in the fall of 2004 by planting two cover crops: cereal rye and crimson clover. Each fall, cover crops were planted with a no-till drill in rows $18 \mathrm{~cm}$ apart in plots $6.1 \mathrm{~m}$ long. Rye was seeded at a rate of $101 \mathrm{~kg} \cdot \mathrm{ha}^{-1}$, whereas clover was seeded at $28 \mathrm{~kg} \cdot \mathrm{ha}^{-1}$. Nitrogen was applied at a rate of $67 \mathrm{~kg} \cdot \mathrm{ha}^{-1}$ on rye plots in early spring each year. The experiment was established on a Hartsells fine sandy loam soil (fine-loamy, siliceous, sub-active, thermic Typic Hapludults). The experimental design was a split plot with four treatment replications. Treatments included two cover crops (cereal rye and crimson clover). For each cover crop treatment, three subsoil shank treatments were used: no shank, slim shank, and wide shank. These treatments were compared with control plots (no cover crops) using plastic mulch, which is typically used for tomato production in Alabama. Each plot was $2.8 \mathrm{~m}$ wide and had a single row of tomatoes in the middle of the plot with $38-\mathrm{cm}$ spacing between plants.

A custom-made, retractable scale was used to measure the height of 10 randomly selected rye and crimson clover plants per plot, which were then averaged to obtain one height per plot. To determine winter cover crop biomass, plants were clipped at the ground from two randomly selected $0.25-\mathrm{m}^{2}$ sections per plot immediately before termination. Plant samples were dried at $70{ }^{\circ} \mathrm{C}$ for $72 \mathrm{~h}$ and weighed to determine dry biomass. The winter cover crops were ended each spring with a mechanical roller crimper before a supplemental chemical application of glyphosate at a rate of $1.0 \mathrm{~kg} \cdot \mathrm{ha}^{-1}$ (a.i.) at the end of April, $\approx 3$ weeks before transplanting 
tomatoes. The roller/crimper used in this experiment was $2.8 \mathrm{~m}$ wide and consisted of a round drum with equally spaced blunt, straight, steel bars around the drum's circumference and across the drum's length (Fig. 1). The function of the bars was to crimp or crush the cover crop stems without cutting them. The rolling process produced a uniform residue cover on the soil surface.

Tomato cultivar Florida 47 seedlings were transplanted on 4 May in 2005, 15 May in 2006, 2 May 2007, and on 1 May in 2008. Seedlings (14 plants per each plot) were planted into both cover crops using a modified RJ No-till transplanter (RJ Equipment, Blenhiem, Ontario, Canada; Fig. 2).

To alleviate the soil-compacted layer, the transplanter was modified by adding a subframe between the toolbar (with a mounted plastic tank for water/startup fertilizer) and the parallel linkage of the transplanter (Fig. 3).

The subframe was able to accommodate both commercially available shanks (subsoilers) and custom-made shanks. Subsoiler shanks were able to penetrate the heavy residue and disrupt a naturally occurring consolidated compacted soil layer to a depth of 30 to $40 \mathrm{~cm}$, which is common at the experimental site in Cullman (Fig. 3). Additionally, in 2007, two driving wheels were used (one wheel on each side of the tomato row) instead of the original single wheel at the center of the row to improve stability and help minimize re-compaction of the soil opening created by the shank. As depicted in Figure 4, two different shanks

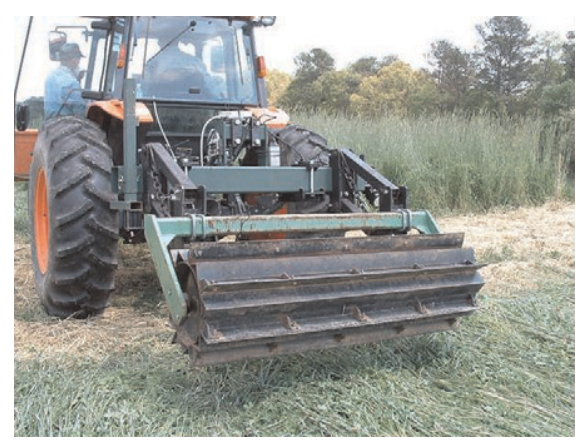

Fig. 1. Rolling cover crops using a 2.8-m straight bar roller/crimper with $6-\mathrm{mm}$ thick blunt crimping bars.

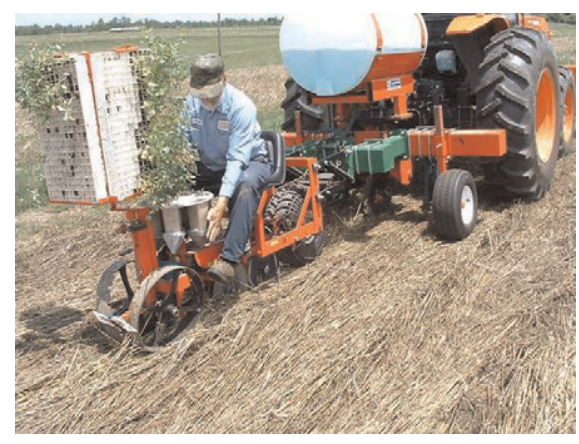

Fig. 2. Planting tomato seedlings into rolled rye residue cover using a modified RJ no-till transplanter from RJ Equipment Company, Blenhiem, Ontario, Canada. were used in the experiment: a slim, 13-mm wide custom shank and a commercially available 20 -mm wide shank.

A day after transplanting tomatoes, 12 temperature sensors were placed below the soil surface on selected plots in the center of the plot to collect soil temperatures $\left(\mathrm{HOBO}^{\circledR}\right.$ Water Temp Pro Model H20-001; Onset Computer Corporation, Pocasset, MA) for different cover treatments during the growing season. To avoid bias in selecting tomato plants to be harvested, tomatoes were hand-picked from all 14 plants in each plot four times at the mature green to pink color stages. Fruit number and fruit weight for total (cull included) extra large, large, medium, and small sizes from each plot were recorded. Data were analyzed by analysis of variance and treatment means were separated using the Fisher's protected least significant differences (LSD) test at the $10 \%$ probability level. Cover and subsoil shank treatments were considered fixed effects and years were considered random effects (Gomez and Gomez, 1984). Where interactions between treatments and weeks or years occurred, data were analyzed separately and where no interactions were present, data were combined using SAS (2001) analysis of variance Analyst's linear model.

\section{Results and Discussion}

Cover crop height and biomass production. Plant heights and dry biomass of rye and crimson clover are shown in Table 1 . There

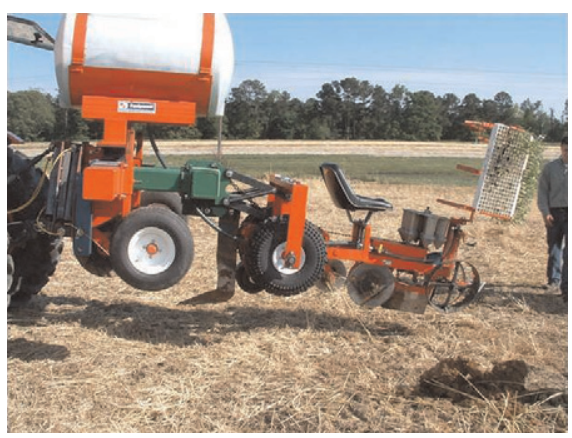

Fig. 3. Side view of the modified RJ transplanter showing the subframe with the subsoiler shank and two ground-driven wheels to power the moving components.

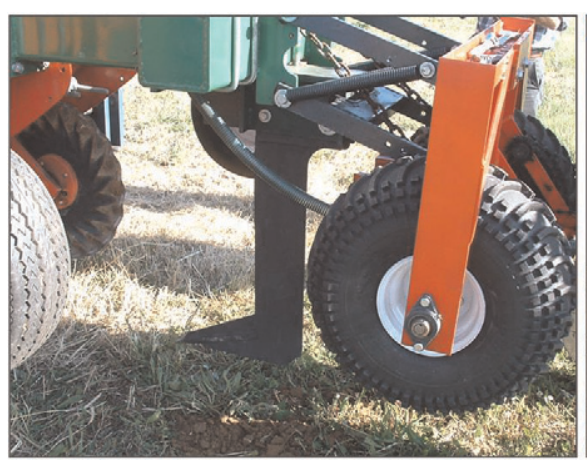

Fig. 4. Two different shank subsoilers used. On the left, the slim $13 \mathrm{~mm}$ thick; and on the right, wide-shank 20 -mm thick mounted on the transplanter. Note that the overall shapes of the two shanks were similar.

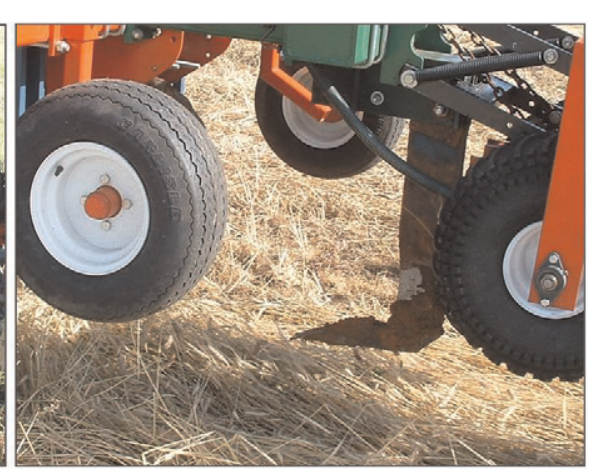

were interactions between years and covers $(P<0.0001)$; thus, the heights for each year were analyzed separately. Overall, the height difference between rye and crimson clover was highly significant among the four growing seasons $(P<0.0001)$. Average rye and crimson clover heights during the four growing seasons were $165.4 \mathrm{~cm}$ and $54.1 \mathrm{~cm}$, respectively. Rye heights in $2005(165.1 \mathrm{~cm})$ and 2006 (165.4 $\mathrm{cm})$ were not significantly different $(\mathrm{LSD}=4.6$ $\mathrm{cm}$ ) but significantly different when compared with 2007 and 2008 (LSD $=4.6 \mathrm{~cm}, P<0.0001)$. The lowest height for rye reported in 2007 $(149.1 \mathrm{~cm})$ was the result of the severe drought that occurred during most of 2007; in contrast, the tallest rye of $181.9 \mathrm{~cm}$ was measured in 2008. For each year, clover heights were not significantly different $(P=0.139)$, although there was a strong trend $(86 \%)$ of lowest height in 2007 as a result of the drought.

Biomass production between rye and crimson clover was significantly different in 2005 , 2006, and 2008 growing seasons ( $P$ between 0.0461 and 0.0698$)$ except for the 2007 growing season $(P=0.8671)$. The average dry biomass produced by rye was $7607 \mathrm{~kg} \cdot \mathrm{ha}^{-1}$ with no differences in rye biomass found among the four growing seasons. In contrast, for crimson clover, there were significant differences among the years $(P=0.0316)$. The lowest clover biomass was observed in 2005 $\left(4198 \mathrm{~kg} \cdot \mathrm{ha}^{-1}\right)$, and the highest was in 2008 $\left(6676 \mathrm{~kg} \cdot \mathrm{ha}^{-1}\right)$. Average biomass produced by crimson clover across all growing seasons was $5335 \mathrm{~kg} \cdot \mathrm{ha}^{-1}$.

Soil temperature for different covers. During 4 years of the experiment, minimum, maximum, and average soil temperatures for all covers were significantly different in all years $(P<0.0001)$. Table 2 shows minimum, maximum, and average temperatures from 2005 to 2008 under plastic mulch, rye, and clover. No significant differences in minimum soil temperature among all covers were reported in any year ( $P$ between 0.13 and 0.888 ) at the $10 \%$ significance level. The minimum temperatures ranged from $12.6{ }^{\circ} \mathrm{C}$ in 2008 to $20.1{ }^{\circ} \mathrm{C}$ in 2007 . As already mentioned, in 2007, a severe drought occurred, which caused rising soil temperatures compared with the imum soil temperature of $47.2{ }^{\circ} \mathrm{C}$ was measured in 2007. In 2005 and 2006, significantly higher maximum temperature of 33 and

HortScience Vol. 46(5) May 2011 other three growing seasons. The highest max- 
$36.1^{\circ} \mathrm{C}$, respectively, was recorded for plastic mulch $(P=0.003$ for 2005 and 0.0002 for 2006), whereas in 2005, the rye cover crop had the lowest maximum temperature of $29.0^{\circ} \mathrm{C}$ (Table 2). In 2006, the maximum temperature for rye cover was 5.6 and $3.5^{\circ} \mathrm{C}$ lower than for plastic and clover, respectively.

No significant differences in maximum temperature among the covers were observed in 2007 and 2008, although a strong trend $(89 \%)$ was evident that rye cover crop maintained a maximum soil temperature that was at least $3.6{ }^{\circ} \mathrm{C}$ lower than for plastic mulch and crimson clover. From 2005 through 2007, the average temperature was significantly different with respect to the covers. Similar to the maximum temperature, rye maintained a significantly lower average temperature compared with plastic mulch and clover cover $\left(23.9^{\circ} \mathrm{C}\right)$. During the same period, a significantly higher average soil temperature was observed with the plastic mulch $\left(25.8^{\circ} \mathrm{C}\right)$. In 2008 , there was no significant differences among the covers $(P=$ 0.215).

Total tomato yield. Total tomato yield in kilograms per hectare was estimated from the tomato yield in each plot. There was a significant interaction between treatments and years $(P=0.0259)$ for total tomato yield; thus, statistical analysis was done individually for each year. In 2005 and 2006, no significant differences were observed in total tomato yield averaged across cover treatments, producing 49,656 $\mathrm{kg} \cdot \mathrm{ha}^{-1}$ and 50,151 $\mathrm{kg} \cdot \mathrm{ha}^{-1}$ of tomato, respectively. Compared with 2005 and 2006, a significantly higher total tomato yield was produced in 2007 $\left(60,115 \mathrm{~kg} \cdot \mathrm{ha}^{-1}\right)$ and $2008\left(58,905 \mathrm{~kg} \cdot \mathrm{ha}^{-1}\right)$ $\left(\mathrm{LSD}=4300 \mathrm{~kg} \cdot \mathrm{ha}^{-1}\right)$. The main reason for lower yields in 2005 was unusually low temperatures in May after planting that hindered plant development and tomato fruiting, especially on the lower part of the plants where few or no fruit developed. In all other years, no such days with prolonged lower temperatures were observed soon after planting. Lower tomato yields in 2006 were possibly caused by delayed flowering and maturing when compared with 2007 and 2008. Rainfall almost occurred daily during a 2-week period in May 2006, and temperatures were somewhat lower this year than in 2007 and 2008. These factors combined likely delayed maturity and fruiting, as evidenced by the lateness of the first harvest relative to the other 3 years (between 10 and $15 \mathrm{~d}$ ).

Total tomato yield for each growing season and each cover is depicted in Figures 5, 6, 7, and 8 for 2005, 2006, 2007, and 2008, respectively. In 2005, no significant differences in total tomato yield were found among the cover and shank treatments $(P=0.7442$; Fig. 5). There was a significant difference in total tomato yield among the covers $(P=$ 0.0843; Fig. 6). Total tomato yield under plastic mulch $\left(60,921 \mathrm{~kg} \cdot \mathrm{ha}^{-1}\right)$ was higher compared with rye no-shank $\left(49,177 \mathrm{~kg} \cdot \mathrm{ha}^{-1}\right)$ and wide-shank $\left(46,132 \mathrm{~kg} \cdot \mathrm{ha}^{-1}\right)$ treatments and clover residue covers, although there was no significant difference between plastic control and slim shank treatments after rye

Table 1. Height and dry biomass of cereal rye and crimson clover cover crops for the 2005 through 2008 seasons.

\begin{tabular}{|c|c|c|c|c|c|c|}
\hline \multirow[b]{2}{*}{$\mathrm{Yr}$} & \multicolumn{2}{|c|}{$\mathrm{Ht}(\mathrm{cm})$} & \multirow{2}{*}{$\begin{array}{c}P \text { for each } \\
\text { year }\end{array}$} & \multicolumn{2}{|c|}{ Dry biomass $\left(\mathrm{kg} \cdot \mathrm{ha}^{-1}\right)$} & \multirow{2}{*}{$\begin{array}{c}P \text { for each } \\
\text { year }\end{array}$} \\
\hline & Rye & Clover & & Rye & Clover & \\
\hline$\overline{2005}$ & $165.1 \mathrm{~A}^{\mathrm{z}} \mathrm{b}^{\mathrm{y}}$ & $56.5 \mathrm{~B}$ & $<0.0001$ & $6572 \mathrm{~A}$ & $4198 \mathrm{Bd}$ & 0.0698 \\
\hline 2006 & $165.4 \mathrm{Ab}$ & $55.5 \mathrm{~B}$ & $<0.0001$ & $7991 \mathrm{~A}$ & $4562 \mathrm{Bbc}$ & 0.0461 \\
\hline 2007 & 149.1 Ac & $51.0 \mathrm{~B}$ & $<0.0001$ & $6194 \mathrm{~A}$ & $5903 \mathrm{Aab}$ & 0.8671 \\
\hline 2008 & $181.9 \mathrm{Aa}$ & $53.3 \mathrm{~B}$ & $<0.0001$ & $9670 \mathrm{~A}$ & $6676 \mathrm{Ba}$ & 0.0572 \\
\hline LSD & 4.6 & NS & LSD & NS & 1390.3 & \\
\hline$P$ value & $<0.0001$ & 0.139 & $P$ value & 0.218 & 0.0316 & \\
\hline
\end{tabular}

${ }^{2}$ Different capital letters and $P$ values in rows denote statistical significance between the height or biomass for rye and crimson clover within each growing season (year).

${ }^{y}$ Different lower case letters in columns and corresponding LSDS with $P$ values (below LSD number) denote statistical significance for the difference in height or biomass of the cover crop among the growing seasons (years) at the $10 \%$ significance level.

LSD $=$ least significant difference; $N S=$ non-significant.

Table 2. Maximum, minimum, and average soil temperature $\left({ }^{\circ} \mathrm{C}\right)$ for different covers during 2005 through 2008 growing seasons.

\begin{tabular}{llccc}
\hline Growing & & \multicolumn{3}{c}{ Soil temperature $\left({ }^{\circ} \mathrm{C}\right)$} \\
\cline { 2 - 5 } season & Cover & Minimum & Maximum & Avg \\
\hline 2005 & Rye & 15.3 & $29.0 \mathrm{~b}^{\mathrm{z}}$ & $23.8 \mathrm{c}$ \\
& Clover & 15.2 & $30.1 \mathrm{~b}$ & $24.1 \mathrm{~b}$ \\
& Plastic & 15.3 & $33 \mathrm{a}$ & $25.2 \mathrm{a}$ \\
& $P$ value & 0.888 & 0.003 & $<0.0001$ \\
& LSD $^{\mathrm{y}}$ & $\mathrm{NS}$ & 1.39 & 0.14 \\
2006 & & & $30.5 \mathrm{c}$ & $24.6 \mathrm{c}$ \\
& Rye & 18.3 & $34.0 \mathrm{~b}$ & $25.3 \mathrm{~b}$ \\
& Clover & 17.9 & $36.1 \mathrm{a}$ & $26.7 \mathrm{a}$ \\
& Plastic & 17.9 & 0.0002 & $<0.0001$ \\
& $P$ value & 0.463 & 1.18 & 0.202 \\
& LSD & N/S & 40.8 & $23.9 \mathrm{c}$ \\
& & & 47.2 & $24.3 \mathrm{~b}$ \\
& Rye & 18.5 & 46.4 & $25.8 \mathrm{a}$ \\
& Clover & 19.0 & 0.721 & 0.0098 \\
& Plastic & 20.1 & $\mathrm{~N} / \mathrm{S}$ & 1.4 \\
& $P$ value & 0.131 & & 23.2 \\
& LSD & NS & 29.3 & 24.3 \\
& & & 33.0 & 24.0 \\
& Rye & 13.4 & 32.9 & 0.215 \\
& Clover & 12.6 & 0.114 & NS \\
\hline
\end{tabular}

${ }^{\mathrm{z}}$ Values of the temperature within columns for each year having the same letters are not significantly different at the $10 \%$ level in the particular year.

${ }^{y}$ Corresponding $P$ values and LSD values for each cover and temperatures in each growing season are presented.

LSD = least significant difference; NS = non-significant

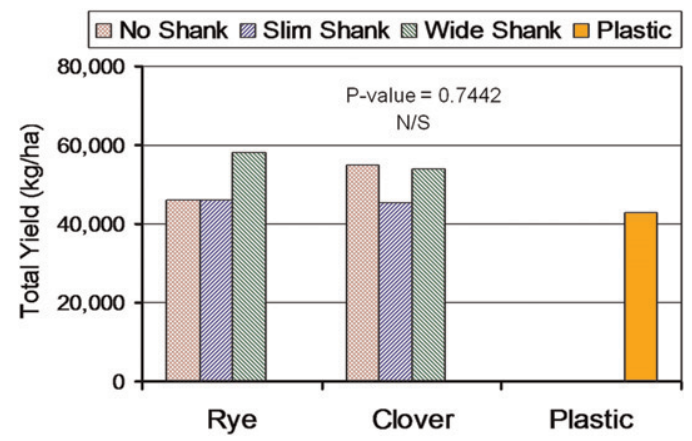

Fig. 5. Total tomato yield during the 2005 growing season.

$\left(53,150 \mathrm{~kg} \cdot \mathrm{ha}^{-1}\right)$ and clover covers $(53,692$ $\mathrm{kg} \cdot \mathrm{ha}^{-1}$ ) (Fig. 6). Similar to 2006, in 2007, there was a significant difference in total tomato yield among the covers $(P=0.0190$; Fig. 7). In 2007, the highest tomato yield was obtained with the rye cover with no-shank $\left(70,577 \mathrm{~kg} \cdot \mathrm{ha}^{-1}\right)$ and wide-shank $(64,094$ $\left.\mathrm{kg} \cdot \mathrm{ha}^{-1}\right)$ treatments. The lowest yield was recorded for plastic $\left(56,711 \mathrm{~kg} \cdot \mathrm{ha}^{-1}\right)$ and crimson clover cover with no shank $(54,703$ $\mathrm{kg} \cdot \mathrm{ha}^{-1}$; Fig. 7). In 2008, significant differences in total tomato yield were observed among all cover treatments $(P<0.0001)$. Significantly higher total tomato yield was 
reported for plastic mulch cover $(73,718$ $\mathrm{kg} \cdot \mathrm{ha}^{-1}$ ) compared with rye cover crop and crimson clover residues. Tomatoes planted into rye residue produced significantly higher total yield (from 60,548 to $62,763 \mathrm{~kg} \cdot \mathrm{ha}^{-1}$ ) compared with crimson clover cover (from 48,430 to $53,626 \mathrm{~kg} \cdot \mathrm{ha}^{-1}$ ). Shank treatments did not have any significant effects on yield in 2008 (Fig. 8).

Marketable tomato yield. The measurable indicator for tomato quality is marketable tomato yield. With total yield, culls are included in the weight. Subtracting the culls weight from the total yield resulted in the marketable quality tomato yield. Equally, years $(P<$ $0.0001)$ and year-by-treatment interactions $(P=0.0319)$ were significant; thus, data were analyzed individually each year. In 2005 , there were no significant differences between cover crop (with three shank treatments) and plastic mulch control ( $P=0.6919$; Fig. 9). The average marketable yield in 2005 was $41,194 \mathrm{~kg} \cdot \mathrm{ha}^{-1}$.

In the 2006 growing season, the average marketable tomato yield was $40,581 \mathrm{~kg} \cdot \mathrm{ha}^{-1}$. Similarly, like in 2005, no significant differences occurred among the cover and shank treatments $(P=0.1637)$, although the numeric value for plastic mulch cover $\left(48,651 \mathrm{~kg} \cdot \mathrm{ha}^{-1}\right)$ was slightly higher than for rye and crimson clover (Fig. 10).

In 2007, the highest marketable yield was calculated for rye with no shank treatment $\left(57,416 \mathrm{~kg} \cdot \mathrm{ha}^{-1}\right)$ in comparison with rye (slim and wide shanks), crimson clover (all shank treatments), and plastic mulch control (Fig. 11). Examining the soil temperature and amount of residue on the soil surface, rye residue without cutting the soil with a shank most likely conserved soil moisture better and provided better weed control compared with other treatments and as a result produced higher marketable tomato yield.

In 2008, the average marketable tomato yield $\left(49,873 \mathrm{~kg} \cdot \mathrm{ha}^{-1}\right)$ was significantly higher than in the 2005 and 2006 growing seasons. Significantly higher marketable tomato yield was found for plastic mulch control $(61,446$ $\mathrm{kg} \cdot \mathrm{ha}^{-1}$ ) compared with rye and crimson clover covers with all shank treatments. Comparing two residue covers and the shank treatments, rye residue cover with slim shank $\left(53,126 \mathrm{~kg} \cdot \mathrm{ha}^{-1}\right)$ and wide shank $(54,269$ $\mathrm{kg} \cdot \mathrm{ha}^{-1}$ ) produced significantly higher marketable yield than crimson clover with all three shank treatments (Fig. 12).

Percentage of marketable tomato versus total yield. Because the percentage of marketable yield each year was different $(P<0.0001)$, data were analyzed separately each year. Percentage of marketable tomato yield with respect to total yield for different treatments during 2005 through 2008 growing seasons is shown in Table 3. Overall, no differences were detected among treatments (cover crops, shanks, and plastic mulch control) for the years 2005 through 2008 indicating that plastic mulch did not improve percentage of marketable fruit. Comparing four growing seasons, a significantly higher percentage $(84.6 \%)$ of marketable tomato to total yield was recorded in 2008 compared with 2005 (82.8\%), 2006

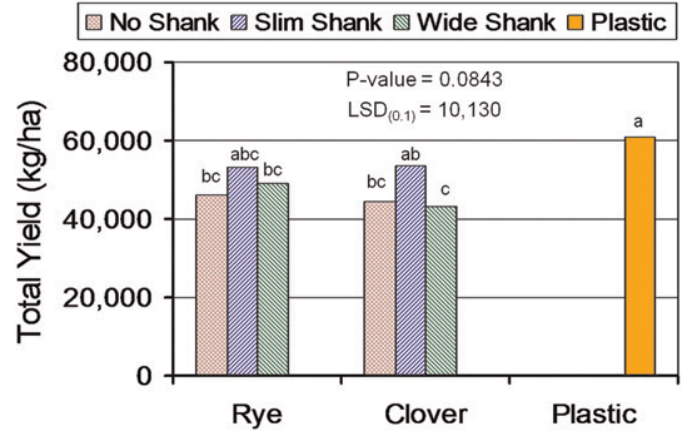

Fig. 6. Total tomato yield during the 2006 growing season.

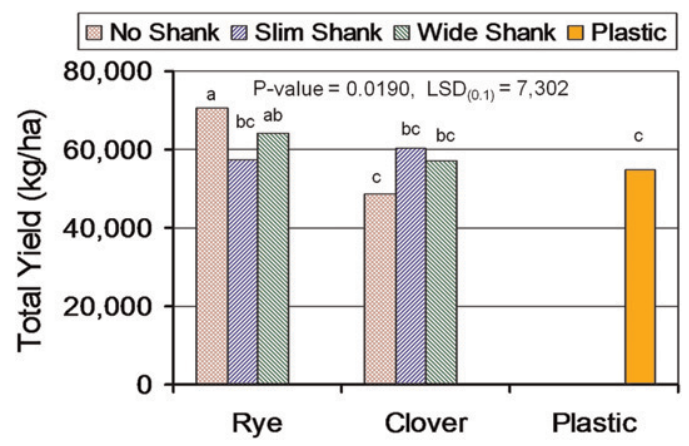

Fig. 7. Total tomato yield during the 2007 growing season.

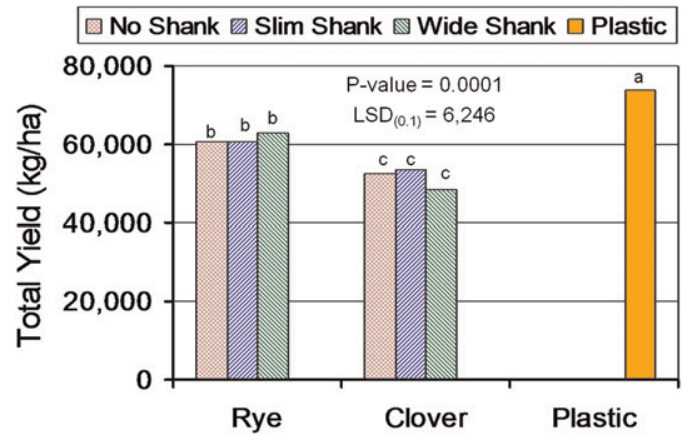

Fig. 8. Total tomato yield during the 2008 growing season.

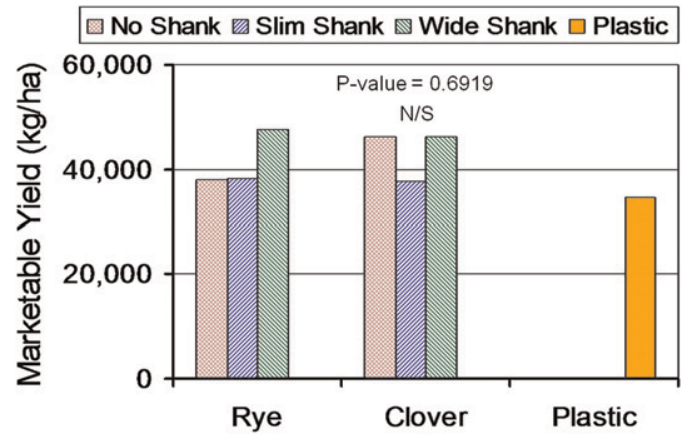

Fig. 9. Marketable tomato yield during the 2005 growing season.

$(80.7 \%)$, and $2007(80.3 \%)(\mathrm{LSD}=1.46 \%)$. In contrast, no significant difference in percentage of marketable tomato yield was detected between 2006 and 2007 growing seasons, but during these seasons, the percentages were significantly lower than during the 2005 and 2008 growing seasons (Table 3; LSD $=1.46 \%$ at the $10 \%$ significance level).

Number of fruits per plant. Equally, year variable $(P<0.0001)$ and interactions between 


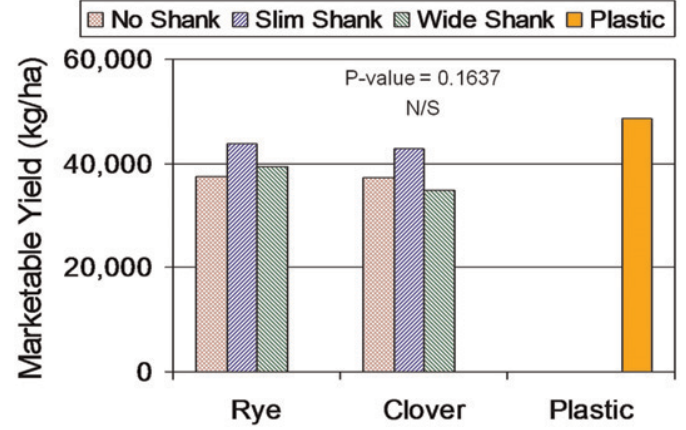

Fig. 10. Marketable tomato yield during the 2006 growing season.

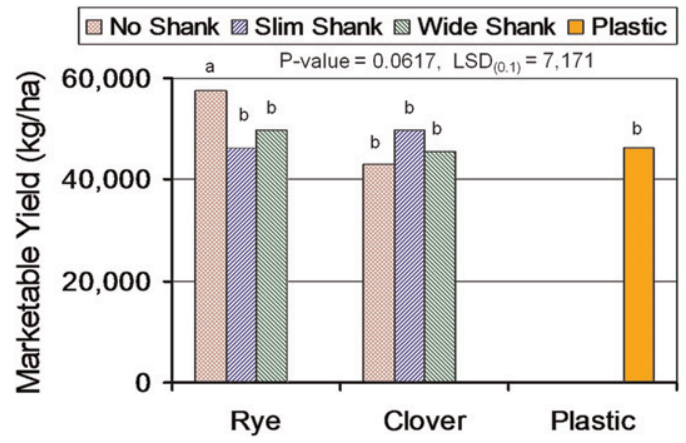

Fig. 11. Marketable tomato yield during the 2007 growing season.

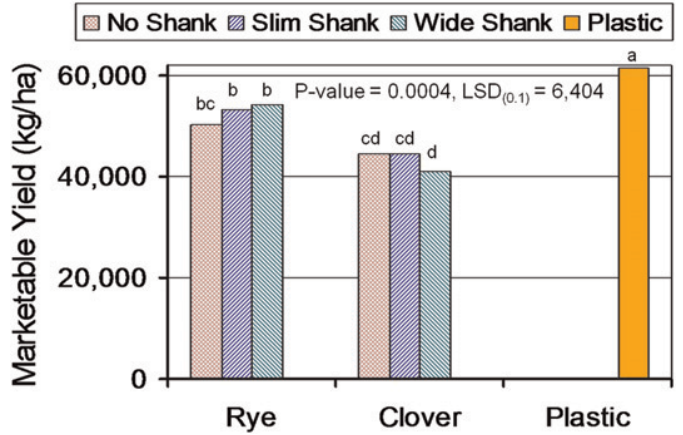

Fig. 12. Marketable tomato yield during the 2008 growing season.

Table 3. Percentage of marketable tomato yield with respect to total yield for different treatments during the 2005 through 2008 growing seasons.

\begin{tabular}{|c|c|c|c|c|c|}
\hline \multirow{2}{*}{$\begin{array}{l}\text { Growing } \\
\text { season }\end{array}$} & \multirow[b]{2}{*}{ Cover } & \multicolumn{3}{|c|}{ Shank treatment } & \multirow{2}{*}{$\begin{array}{c}\text { Overall mean Across } \\
\text { all treatments ( } \mathrm{LSD}=1.46 \%)\end{array}$} \\
\hline & & No shank & Slim shank & Wide shank & \\
\hline \multirow[t]{4}{*}{2005} & Rye & 82.5 & 82.9 & 82.7 & \multirow{4}{*}{$82.8 \mathrm{~b}^{\mathrm{x}}$} \\
\hline & Clover & 83.9 & 82.7 & 84.6 & \\
\hline & Plastic & 79.9 & $\mathrm{~N} / \mathrm{A}^{\mathrm{z}}$ & N/A & \\
\hline & $P$ value & & $0.771^{\mathrm{y}}$ & & \\
\hline \multirow[t]{4}{*}{2006} & Rye & 81.3 & 82.1 & 79.7 & \multirow[t]{4}{*}{$80.7 \mathrm{c}$} \\
\hline & Clover & 82.8 & 79.6 & 79.6 & \\
\hline & Plastic & 79.5 & N/A & N/A & \\
\hline & $P$ value & & 0.593 & & \\
\hline \multirow[t]{4}{*}{2007} & Rye & 81.3 & 80.8 & 77.4 & \multirow[t]{4}{*}{$80.3 \mathrm{c}$} \\
\hline & Clover & 78.8 & 82.0 & 79.8 & \\
\hline & Plastic & 81.7 & $\mathrm{~N} / \mathrm{A}$ & N/A & \\
\hline & $P$ value & & 0.260 & & \\
\hline \multirow[t]{4}{*}{2008} & Rye & 83.1 & 87.6 & 86.5 & \multirow[t]{4}{*}{$84.6 \mathrm{a}$} \\
\hline & Clover & 84.4 & 83.2 & 84.4 & \\
\hline & Plastic & 83.1 & N/A & N/A & \\
\hline & $P$ value & & 0.243 & & \\
\hline
\end{tabular}

${ }^{\mathrm{z}} \mathrm{N} / \mathrm{A}=$ not applicable (no shanks were used for plastic cover).

${ }^{y} P$ values are related to differences among all treatments in each growing season.

${ }^{\mathrm{x}}$ Similar letters within the overall mean (last column) denotes no significant differences among years. years and treatments $(P=0.0225)$ were significant; therefore, data for each year were analyzed separately. No significant differences in fruits/plant were detected between 2008 (24.8 fruits/plant) and 2006 (23.8 fruits/plant) and between 2006 and 2007 (23.2 fruits/ plant). A significantly lower number of fruits/ plant was reported for 2005 (18.8 fruits/plant). Number of fruits/plant results are shown in Table 4. In 2005, 2006, and 2007, there were no significant differences detected among all covers ( $P$ between 0.125 and 0.360 ). In 2008 , a significantly higher number of fruits/plant was reported for plastic cover (30 fruits/plant). Also, no differences were found among shank treatments for rye (25 to 27 fruits/plant) and among shanks for clover (22 to 23 fruits/plant) in the 2008 growing season.

Overall in all growing seasons, no differences were detected among rye and clover with slim shank and rye without shank treatments. A lower number of fruits per plant with crimson clover in 2008 for no-shank and wideshank treatments may have been the result of higher weed competition because clover biomass was low and unevenly covered the soil compared with the higher rye residue. In fact, in 2008, crimson clover biomass production was significantly lower $\left(6676 \mathrm{~kg} \cdot \mathrm{ha}^{-1}\right) \mathrm{com}$ pared with $9670 \mathrm{~kg} \cdot \mathrm{ha}^{-1}$ for rye biomass $(P=$ $0.057)$.

Table 4. Average number of tomato fruits per plant for different treatments during the 2005 through 2008 growing seasons.

\begin{tabular}{|c|c|c|c|c|}
\hline \multirow[b]{2}{*}{$\begin{array}{l}\text { Growing } \\
\text { season }\end{array}$} & \multirow[b]{2}{*}{ Cover } & \multicolumn{3}{|c|}{ Shank treatment } \\
\hline & & $\begin{array}{l}\text { No } \\
\text { shank }\end{array}$ & $\begin{array}{c}\text { Slim } \\
\text { shank }\end{array}$ & $\begin{array}{l}\text { Wide } \\
\text { shank }\end{array}$ \\
\hline \multirow[t]{5}{*}{2005} & Rye & 20.1 & 17.6 & 24.2 \\
\hline & Clover & 20.1 & 15.6 & 19.6 \\
\hline & Plastic & 14.4 & $\mathrm{~N} / \mathrm{A}^{\mathrm{y}}$ & N/A \\
\hline & $P$ value & & $0.125^{z}$ & \\
\hline & LSD & & NS & \\
\hline \multirow[t]{5}{*}{2006} & Rye & 24.3 & 25.7 & 24.4 \\
\hline & Clover & 20.8 & 25.2 & 20.8 \\
\hline & Plastic & 25.5 & N/A & N/A \\
\hline & $P$ value & & 0.360 & \\
\hline & LSD & & NS & \\
\hline \multirow[t]{5}{*}{2007} & Rye & 25.7 & 21.9 & 24.1 \\
\hline & Clover & 20.6 & 24.1 & 21.9 \\
\hline & Plastic & 23.7 & N/A & N/A \\
\hline & $P$ value & & 0.205 & \\
\hline & LSD & & NS & \\
\hline \multirow[t]{5}{*}{2008} & Rye & $25 b^{z}$ & $25 \mathrm{bc}$ & $27 \mathrm{~b}$ \\
\hline & Clover & $22 \mathrm{~d}$ & $23 \mathrm{~cd}$ & $22 \mathrm{~d}$ \\
\hline & Plastic & $30 \mathrm{a}$ & N/A & $\mathrm{N} / \mathrm{A}$ \\
\hline & $P$ value & & 0.0006 & \\
\hline & LSD & & 2.7 & \\
\hline
\end{tabular}

${ }^{\mathrm{z}}$ Values of the means among cover crop and shank treatments (within rows and columns in each year) having the same letters are not significantly different at the $10 \%$ level; LSD and $P$ values are related to the number of tomato fruits per plant means among cover crop and shank treatments in each growing season.

${ }^{\mathrm{y}} \mathrm{N} / \mathrm{A}=$ not applicable.

LSD $=$ least significant difference; $\mathrm{NS}=$ nonsignificant. 


\section{Conclusion}

In one of four growing seasons (2008), tomatoes planted into plastic mulch cover produced higher total yield and number of fruit per plant. In 2007, when a severe drought occurred, tomatoes planted into rye residue (without shank) produced significantly higher total and marketable yield in comparison with the plastic mulch control and clover, indicating that the rye cover crop was better for conserving soil water for tomato use. Cover crops and shank treatments did not affect percentage of marketable tomato yield compared with total tomato yield.

Inexplicably, the minimum temperature for rye was higher compared with plastic and clover in 2008. In 2 years (2005 and 2006), there were no differences among treatments in total marketable tomato yield. In 2007, greater total marketable yield was recorded with rye cover and no shank. However, the plastic cover produced the greatest total marketable tomato yield. Because maximum temperature under clover during 4 years was higher than rye, it appears that higher temperature and lower clover biomass production lead to incomplete soil cover, resulting in more weed pressure and lower water availability that affected tomato yield. Use of a rye cover crop appears to be a feasible alternative to plastic mulch for tomato production in Alabama.

\section{Literature Cited}

Abdul-Baki, A.A., J.R. Teasdale, R. Korcak, D.J. Chitwood, and R.N. Huettel. 1996. Fresh-market tomato production in a low-input alternative system using cover crop mulch. HortScience 31:65-69.

Ashford, D.L. and D.W. Reeves. 2003. Use of a mechanical roller crimper as an alternative kill method for cover crop. Amer. J. Altern. Agr. 18:37-45.

Barnes, J.P. and A.R. Putnam. 1983. Rye residues contribute weed suppression in no-tillage cropping systems. J. Chem. Ecol. 9:10451057.

Blough, R.F., A.R. Jarrett, J.M. Hamlett, and M.D. Shaw. 1990. Runoff and erosion water from silt, conventional, and chisel tillage under simulated rainfall. Trans. ASAE 33:1557-1562.

CTIC. 2004. Conservation tillage trends 19902004. National Crop Residue Management Survey. Conservation Technology Information Center, West Lafayette, IN.

Derpsch, R., C.H. Roth, N. Sidiras, and U. Köpke. 1991. Controle da erosão no Paraná, Brazil Sistemas de cobertura do solo, plantio directo e prepare conservacionista do solo. Deutsche
Gesellschaft für Technische Zusammenarbeit (GTZ) GmbH, Eschborn, Germany.

Gomez, K.A. and A.A. Gomez. 1984. Statistical procedures for agricultural research. 2nd Ed. John Wiley \& Sons, Inc., New York, NY.

Hubbell, D.H. and J.B. Sartain. 1980. Legumes-A possible alternative to fertilizer nitrogen. Fla. Coop. Ext. Serv. Circular SL-9.

Kornecki, T.S., R.L. Raper, F.J. Arriaga, E.B Schwab, and J.S. Bergtold. 2009. Impact of rye rolling direction and different no-till row cleaners on cotton emergence and yield. Trans. ASABE 52:383-391.

Mahboubi, A.A., R. Lal, and N.R. Faussey. 1993. Twenty-eight years of tillage effects on two soils in Ohio. Soil Sci. Soc. Amer. J. 57:506512.

Mansoer, Z.D., W.R. Reeves, and C.W. Wood 1997. Suitability of sunn hemp as an alternative late-summer legume cover crop. Soil Sci. Soc. Amer. J. 61:246-253.

Reeves, D.W. 1994. Cover crops and rotations, p. 125-172. In: Hatfield, J.L. and B.A. Stewart (eds.). Advances in soil science: Crops residue management. Lewis Publ., Boca Raton, FL.

SAS. 2001. Proprietary software release V8.2. SAS Institute, Inc., Cary, $\mathrm{NC}$

Teasdale, J.R. and A.A. Abdul-Baki. 1995. Soil temperature and tomato growth associated with black polythene and hairy vetch mulches. J. Amer. Soc. Hort. Sci 120:848-853. 